\title{
A CONDIÇÃO JURÍDICA DAS MULHERES SOLTEIRAS NA PENÍNSULA IBÉRICA MEDIEVAL A PARTIR DO FUERO REAL E DO LIVRO DAS LEIS E POSTURAS
}

\section{SINGLE WOMEN LEGAL STATUS IN THE MEDIEVAL IBERIAN PENINSULA BASED ON THE FUERO REAL AND THE BOOK OF LAWS AND POSTURES}

Marta de Carvalho Silveira ${ }^{1}$

\begin{abstract}
Resumo: $O$ estudo da condição jurídica feminina no século XXI tem sido alvo de estudos tanto no campo do Direito quanto da História graças às demandas da própria sociedade contemporânea. O que suscita duas reflexões: a fluidez inerente à noção da identidade jurídica feminina e a influência que a cultura medieval exerce sobre a elaboração da identidade feminina atual. É para contribuir com esse debate que analisaremos alguns dos elementos que influenciaram na elaboração de uma concepção jurídica acerca das mulheres medievais a partir da comparação de dois dos códigos legais fundantes de grande parte da tradição jurídica latino-americana: o Fuero Real e o Livro das Leis e Posturas. O objetivo deste artigo é, portanto, identificar e comparar na documentação selecionada alguns aspectos jurídicos que envolvem a atribuição de papéis sociais às mulheres solteiras nos reinos de Castela e Portugal no século XIII.
\end{abstract}

Palavras-chaves: História das mulheres. Direito medieval. Fuero Real. Livro das leis e Posturas.

Abstract: The study of the legal status of women in the 21st century has been the subject of studies both in the field of Law and History thanks to the demands of contemporary society itself. This raises two reflections: the fluidity inherent in the notion of female legal identity and the influence that medieval culture exerts on the elaboration of the current female identity. It is to contribute to this debate that we will analyze some of the elements that influenced the elaboration of a legal conception about medieval women, based on the comparison of two of the founding legal codes of a large part of the Latin American legal tradition: the Fuero Real and the Livro das Laws and Postures. The purpose of this article is, therefore, to identify and compare in the selected documentation some legal aspects involving the

\footnotetext{
${ }^{1}$ Possui Graduação e Licenciatura em História pela Universidade Federal do Rio de Janeiro (1993), Mestrado em História Social pela Universidade Federal do Rio de Janeiro (1996) e Doutorado em História Antiga e Medieval pela Universidade Federal Fluminense (2012). Atualmente é Professora Adjunta da Universidade do Estado do Rio de Janeiro, onde atua na área de História Medieval. Leciona também no ensino fundamental, na Secretaria Municipal de Educação do Rio de Janeiro. Tem experiência na área de História, com ênfase em História Antiga e Medieval, atuando principalmente nos seguintes temas: Política, Direito, Península Ibérica, História das mulheres.
} 
Revista da Seção Judiciária do Rio de Janeiro

assignment of social roles to single women in the kingdoms of Castile and Portugal in the 13 th century.

Keywords: History of women. Medieval law. Fuero Real. Book of laws and Postures.

Recebido em: $16 / 11 / 2021$ Aceito para publicação em: 29/11/2021 
Revista da Seção Judiciária do Rio de Janeiro

\section{INTRODUÇÃO}

A década de 1960 trouxe à cena social o movimento feminista. As mulheres chegaram às universidades e se tornaram tanto produtoras de um conhecimento intelectual quanto um objeto de estudo. A História, que privilegiara até aquele momento o chamado sujeito universal masculino, ganhou novos protagonistas que foram além dos grandes personagens masculinos e dos heróis nacionais. As mulheres e outros grupos sociais desconsiderados até aquele momento pelos estudos historiográficos conquistaram espaço no âmbito acadêmico.

Sem dúvida a interação crescente com os estudos antropológicos, particularmente com a obra de Claude Lévi-Strauss, que focava na análise do papel que as relações de parentesco alcançavam na configuração das sociedades ditas primitivas, estimulou e fundamentou a exploração de novos temas pelos historiadores, tais como o estudo das relações matrimoniais e dos papéis sociais femininos.

Influenciados pela antropologia estruturalista, os medievalistas da década de 1970, capitaneados por estudiosos como Georges Duby, iniciaram uma reflexão mais aprofundada sobre o papel que o casamento alcançou na estruturação da sociedade feudal. Nas obras Idade Média, Idade dos Homens (1989) e O cavaleiro, a mulher e o padre (1981), Duby refletiu profundamente sobre a importância que o casamento desempenhou na configuração das relações políticas, econômicas e sociais das casas nobiliárquicas medievais. Ampliando a sua reflexão sobre a condição feminina na Idade Média, Duby produziu uma série de estudos específicos sobre a história das mulheres, tais como os três volumes intitulados Damas do século XII (1997) e organizou a coleção História das Mulheres em parceria com Michelle Perrot, uma das historiadoras que contribuiu significativamente para a construção teórica e metodológica de uma história social das mulheres. 
Revista da Seção Judiciária do Rio de Janeiro

Além da inovação temática, as referidas obras propuseram também o uso de novos métodos de análise e fontes para o estudo da história das mulheres. A contribuição das obras produzidas por Duby foi fundamental para a análise da dominação masculina sobre as mulheres na Idade Média e para além dela, ao desvelar aos historiadores a riqueza inerente ao estudo do universo feminino medieval em seus mais diversos matizes.

Foi justamente buscando explorar outros matizes em torno do estudo das mulheres medievais é que realizamos esta pesquisa, tendo como foco a análise das proposições jurídicas referentes às mulheres solteiras no âmbito de um discurso normativo castelhano e português. Contudo, é inegável que, no contexto medieval, as determinações legais encontravam-se imersas em uma cultura intelectual religiosa, tomando como base os parâmetros morais cristãos em seu processo de elaboração. Logo, em nossa análise, consideramos o modelo social feminino pautado nos princípios morais cristãos, difundido pelo discurso religioso e aquele que foi propagado pelas monarquias ibéricas a partir da legislação, sendo este último o nosso objeto de estudo específico.

Nossa análise, portanto, encontra-se circunscrita ao campo do político, mas em constante diálogo com os demais aspectos da sociedade medieval, especialmente aqueles que se referem à condição social feminina. Assim como René Rémond não reivindicamos para o político a hegemonia e nem pretendemos "que tudo seja político", mas constatamos que "o político é o ponto para onde conflui a maioria das atividades e que recapitula os outros componentes do conjunto social." (RÉMOND, 2003, p. 447).

Para tanto serão utilizados como fontes de pesquisa o Fuero Real e o Livro das Leis e Posturas. Ambas as fontes são códigos jurídicos produzidos no século XIII, nos reinos de Castela e Portugal, respectivamente, sendo frutos do esforço centralizador que moveu os monarcas ibéricos em um contexto onde as disputas

\footnotetext{
${ }^{2}$ Para facilitar a redação e a leitura passaremos a utilizar as abreviaturas FR para Fuero Real e LLP para o Livro das leis e posturas.
} 
Revista da Seção Judiciária do Rio de Janeiro

políticas internas contrapunham as forças monárquicas, nobiliárquicas e municipais, e as disputas externas opunham cristãos e muçulmanos na luta pela ocupação do território peninsular.

Através de uma análise comparativa desses códigos jurídicos, tendo como variantes comparáveis, as determinações legais referentes às mulheres solteiras em relação à propriedade e à gestão de bens, e ao comportamento social moral e juridicamente adequado, pretendemos contribuir tanto para um melhor entendimento dos espaços de ação legalmente garantido a essas mulheres quanto aos mecanismos legais que promoviam a sua submissão à tutela masculina.

Para tanto, na primeira parte do texto, as fontes primárias e o seu contexto de produção foram apresentados, em seguida realizamos a análise cruzada do FR e do LLP tendo como dados comparativos os elementos apontados anteriormente.

\section{O FUERO REAL, O LIVRO DAS LEIS E POSTURAS E O SEU CONTEXTO DE PRODUÇÃO}

O século XIII foi marcado politicamente pelo processo de consolidação das monarquias ocidentais e de elaboração de mecanismos jurídicos que fundamentassem a autoridade régia e garantissem o poder ordenador do monarca sobre o corpo social. Grande parte da fundamentação jurídica para a produção desses mecanismos foi encontrada no direito romano e no direito canônico, resgatado e produzido, respectivamente, a partir dos esforços reformistas que moveram a Igreja no século XII. Parte desses esforços consistiu na elaboração da noção de teocracia papal tendo como base, sobretudo, o direito romano resgatado e detalhadamente estudado no âmbito eclesiástico.

Brenda Bolton (1983), ao analisar a reforma eclesiástica do século XII, destacou a importância que as transformações políticas, econômicas e sociais ocorridas em fins do século XI e início do século XII tiveram na fermentação de 
Revista da Seção Judiciária do Rio de Janeiro

novas concepções acerca da espiritualidade, tanto entre os laicos quanto entre os clérigos, ansiosos por novos modelos de espiritualidade que implicassem em uma vivência mais individual da religião e "um ingresso evangélico no mundo.". Em resposta a essa demanda e motivada pelo desejo de libertar-se das amarras que a aristocracia impunha sobre as igrejas locais, controlando os cargos e o patrimônio eclesiástico, o papado romano investiu em um conjunto de reformas que envolveram a produção de normativas que visavam ordenar o comportamento dos clérigos e dos laicos e na codificação das leis canônicas.

O resgate do direito romano foi um fator fundamental na configuração do direito canônico a partir do qual o papado garantiu o seu papel de liderança sobre a igreja, submetendo juridicamente os clérigos, os cargos e as propriedades eclesiásticas diretamente ao seu poder. Com essas medidas, pretendia-se inibir a ameaça constante que a nobreza e os monarcas representavam ao patrimônio eclesiástico distribuído por todo o ocidente medieval. Ao analisar a importância que 0 direito canônico alcançou na história jurídica ocidental. Antônio Schioppa afirmou que:

\begin{abstract}
O desenvolvimento posterior do direito canônico dos séculos XII e XIII está em estreita ligação com algumas escolhas efetivadas na época da reforma: entre elas, a centralização e a supremacia pontifícia, tanto naquilo que se refere à normatização como por meio do instrumento das apelações a Roma, a autonomia da Igreja em relação aos poderes temporais, a desvinculação com a servidão do sistema feudal e de vassalagem, o celibato eclesiástico. A tradição jurídica e institucional da Igreja Católica será diretamente influenciada por isso até o século XX. (SCHIOPPA, 2014, p. 55).
\end{abstract}

A luta pela ascensão do poder monárquico em detrimento do poder nobiliárquico inspirou aos reis do século XIII a cercar-se da chancela jurídica para referendar o potencial centralizador do seu poder. Cada monarca, dentro das especificidades políticas e culturais dos seus reinos, mantinha em suas cortes juristas capazes de elaborar códigos legais que dialogassem com a tradição jurídica local, 
Revista da Seção Judiciária do Rio de Janeiro

reunida no chamado direito consuetudinário, e que se inspirassem nas inovações legais trazidas pelo direito romano revisto e pelo direito canônico recém-estruturado.

Historiadores do direito, como o já mencionado Antonio Schioppa, seguido de Bartolomé Clavero e Paolo Prodi, consideram tão importante o saber jurídico produzido no século XII que localizaram ali o chamado "renascimento jurídico". Merece destaque como centro intelectual desse período a cidade de Bolonha, onde os estudos jurídicos alcançaram a sua mais vigorosa produtividade, expressa no estudo dos textos legais do direito romano clássico, como o Digesto, o Codicis Iustiniani, as Instituições e as Novelas que resultaram na produção de um vasto material glosadístico. Em reconhecimento à vigorosa produção jurídica desse período, B. Clavero nele situou não só o chamado "renascimento jurídico", mas também a formação da "ciência do direito que foi elaborada nas universidades a partir do século XIII". (CLAVERO, 1995, p. 202)

Na Península Ibérica, o século XIII foi marcado pela expansão do poderio dos reinos cristãos do norte que, desde o século $\mathrm{XI}$, investiram na organização da sua força militar para o combate das tropas muçulmanas. Especialmente a partir da conquista de Toledo (1085), as forças cristãs foram ocupando de forma lenta, mas progressiva, o território peninsular.

À conquista militar do território seguia-se o esforço para o seu devido repovoamento, que envolvia a dinamização econômica das áreas recém-reconquistadas, a ampliação das áreas agrícolas e dos rebanhos, além do incremento das atividades comerciais e artesanais, que favoreceram a preservação da posição decisiva da península na rota mediterrânica e no incremento do comércio interno e da rede urbana.

Afonso X, de Castela (1221-1284), e os reis portugueses da dinastia de Borgonha partilhavam de desafios similares. Viam-se compelidos a garantir a continuidade das atividades de conquista territorial que os envolvia em conflitos constantes com as forças muçulmanas peninsulares e com os monarcas cristãos 
Revista da Seção Judiciária do Rio de Janeiro

vizinhos. Além disso, precisavam garantir o apoio político e bélico da aristocracia interessada em manter seus privilégios territoriais, políticos e jurídicos sobre os municípios, que tendiam a requerer do monarca medidas que preservassem a sua autonomia frente às forças aristocráticas. Foi esse o quadro contextual que motivou a redação do FR e do LLP.

O FR e o LLP são documentos jurídicos que se caracterizam por reunir um conjunto de leis que tratam de temas diversos. Os direitos canônico e romano acrescidos de elementos do direito consuetudinário embasaram a elaboração dos dois códigos. Entretanto, enquanto o FR foi redigido nos moldes previstos no direito romano, reunindo os assuntos tratados em livros específicos, subdivididos em títulos e leis, que obedeciam a uma organização temática, o LLP sofreu uma forte influência do direito consuetudinário expressa na forma como as leis encontram-se dispostas no código. O LLP não é dividido em livros e sim em títulos que reúnem as determinações legais. Logo, as temáticas jurídicas presentes no texto não foram diferenciadas e organizadas dentro de uma lógica específica. O texto mostra-se mais como um registro de algumas determinações legais ditadas pelo monarca tanto para reforçar algumas práticas consuetudinárias quanto para alterá-las. Além disso, no LLP é possível encontrar "modelos de cartas de requerimento" às instâncias governamentais.

A tradição jurídica castelhana era longa e remontava aos primeiros esforços realizados por Afonso VI para estabelecer uma política de distribuição de cartas forais (fueros) que regulavam, sobretudo, a ocupação dos territórios retomados dos muçulmanos. Além disso, um dos fundamentos ideológicos da monarquia castelhana, propagada, sobretudo, na literatura cronística do século XIII era o da hegemonia do reino castelhanoleonês sobre os demais reinos peninsulares. Foi com base nessa tradição jurídica e na demanda política de garantir o pleno exercício do seu poder sobre os súditos castelhanos e leoneses, em um contexto de reunificação das duas coroas, que Fernando III (1201-1252) mandou produzir o Fuero Juzgo, em 1241. 
Revista da Seção Judiciária do Rio de Janeiro

O mesmo caminho de uso da legislação como instrumento para a definição e a justificação dos mecanismos de exercício da autoridade monárquica foi trilhado por seu filho e sucessor, Afonso X (1221-1284), que reuniu em torno de si, juristas como Jacobo de las leyes (1220-1294), formado em Borgonha e um dos principais organizadores da vasta obra legislativa produzida na corte afonsina, composta pelo FR, as Siete Partidas e o Espéculo.

A data de composição do FR é controversa. Nesse artigo acatamos a hipótese defendida por Iglesia Ferreirós (1980), de que essa obra foi redigida na corte afonsina, integrando o projeto político-jurídico do monarca e sendo parte de uma trajetória legislativa que remontava ao século XII. O FR foi concedido, em 1255, inicialmente às municipalidades de Castilla la Vieja, e progressivamente foi estendido à região da Extremadura, Transierra, Toledo, Andaluzia e Múrcia, com o objetivo de sobrepor-se aos fueros locais utilizados nessas regiões.

Escrito em castelhano, no scriptorium afonsino, o FR foi dividido em quatro livros subdivididos em 72 títulos e 550 leis que tratam de diversos assuntos, desde a própria definição da autoridade régia e das condições do seu exercício, passando pelo estabelecimento dos mecanismos processuais e pelo trato de diversas questões cotidianas que, normatizadas, garantiam a estabilidade social.

Apesar de hoje ser reconhecido pelos estudiosos do direito medieval como um dos códigos jurídicos mais completos e bem estruturados do período, em seu contexto, o FR enfrentou a resistência de boa parte da aristocracia castelhana para a sua implantação. Descontente com a perda dos recursos obtidos com a aplicação da justiça como previam os fueros locais, a aristocracia castelhana deflagrou, em 1272, uma revolta contra essas e outras medidas adotadas pelo monarca que implicariam na perda de alguns dos seus privilégios e recursos. Algumas famílias de ricoshombres do reino ameaçaram transferir a sua lealdade para o rei de Granada. Diante dessa rebelião, Afonso $X$ retirou a obrigatoriedade do uso do FR em todo o reino e tornou-o uma espécie de material que deveria ser consultado quando alguma questão jurídica 
Revista da Seção Judiciária do Rio de Janeiro

sem precedente nos fueros regionais necessitasse de resolução. Foi somente no reinado de Afonso XI, já no século XIV, que o FR sobrepôs-se sobre os demais códigos vigentes no reino castelhano-leonês e tornou-se a referência jurídica única no reino.

Desde a formação do reino português, no século XII, os reis borgonheses se viram envolvidos em embates com forças externas que constantemente influenciavam no equilíbrio das forças internas de poder, traduzindo-se em rebeliões e oposições monárquicas que se arrastaram ao longo dos séculos XII e XIII e que constantemente colocavam em campos opostos os membros da própria dinastia. É o caso, por exemplo, da ascensão de Afonso III, o Bolonhês (1210 a 1279), ao poder logo após a disputa militar que travou com seu irmão, o rei Sancho II, pelo controle da Coroa. Tal conflito lançou o reino em uma intensa guerra civil alimentada por uma aristocracia ávida pelo controle de mais territórios e de ampliação do alcance do seu poder político.

Através de uma bula papal que lhe garantia plenos poderes sobre o reino português, o infante Afonso III chegou a Lisboa, provavelmente entre o fim de 1245 e o início de 1246, sendo bem acolhido pela burguesia lisboeta e portando o título de "defensor e visitador do reino" concedido pelo Sumo Pontífice Inocêncio IV, o que despertou forte oposição entre as forças nobiliárquicas do Norte.

O rei Sancho II viu-se isolado em Coimbra, mas contou com a proteção de alguns nobres. Para livrar-se das tropas de seu irmão, recorreu à ajuda do rei castelhano Fernando III que, ocupado com os embates travados contra os muçulmanos na fronteira Sul do seu reino, deixou a cargo de seu filho, o infante Afonso $X$, o socorro ao seu aliado. Afonso X, então, dirigiu-se a Portugal com suas tropas transpondo a fronteira de Côa, no ano de 1247, e se estabeleceu em Coimbra, onde lutou contra as forças do Bolonhês, que guerreavam ao sul do rio Mondego.

Após algumas derrotas, as tropas castelhanas terminaram vencidas e se retiraram para Castela levando consigo Sancho, o rei deposto, que morreu exilado, 
Revista da Seção Judiciária do Rio de Janeiro

no ano seguinte, na corte castelhana (1248). A nobreza do Norte ampliou a sua oposição ao novo monarca e para submetê-la, Afonso III abriu caminho com os seus exércitos pela região situada entre o Douro e o Minho em busca do apoio político da nobreza local, de forma voluntária ou não.

Afonso III, então, assumiu a Coroa com o apoio de setores da nobreza, da Igreja e dos concelhos municipais. O novo rei tinha diante de si o desafio de promover a centralidade do poder real que pudesse fazer frente às forças opositoras compostas pelos apoiadores do seu irmão. Um dos primeiros passos dados pelo monarca, após ter a sua autoridade régia reconhecida, foi confirmar todos os foros e as regalias da burguesia lisboeta, justamente para conseguir o apoio necessário na luta contra as forças setentrionais que permaneciam fiéis ao rei deposto. Este ato representou, sem sombra de dúvida, um marco na relação que se estabeleceria futuramente entre a burguesia portuguesa e os seus monarcas, já que a partir daí ela passaria a ser ouvida nas Cortes gerais do reino.

A confirmação da autonomia jurídica dos concelhos municipais se deu também em outras regiões do reino conforme o monarca avançava com o seu exército em direção ao Norte, contribuindo para a mobilização de mais tropas e a ampliação da sua autoridade política e para que os vilões dos concelhos se sentissem mais seguros diante da violência das tropas de alguns nobres setentrionais. Segundo nos informa Mattoso, durante este período o monarca empenhou-se em:

[...] captar o apoio dos nobres da região, a exigir-lhes a homenagem vassálica ou o reconhecimento público da sua autoridade e a tomar medidas destinadas a impor a ordem numa região profundamente abalada pela anarquia dos anos anteriores." (MATTOSO, 2001, p. 903).

Após apaziguar os conflitos internos gerados pela guerra civil em que mergulhou o reino, Afonso III fixou-se na cidade de Lisboa, tornando-a a sede do seu reino. O monarca, então, parecia estar pronto para o seu segundo desafio: consolidar o controle português sobre a região do Algarve, seguindo uma tendência 
Revista da Seção Judiciária do Rio de Janeiro

já iniciada por seus antecessores que procuraram estender as fronteiras portuguesas para o Sul, o que o colocou em rota de colisão com os interesses castelhanos (RUCQUOI, 2005, p. 196).

Em seu artigo O triunfo da monarquia portuguesa: 1258-1264. Ensaio de história política (2001), José Mattoso identificou duas datas fundamentais para o triunfo da perspectiva centralista do poder monárquico em Portugal: 1258 (o momento em que o rei Afonso III levantou as primeiras inquirições) e 1264 (a data da última das decisões seminais tomadas por Afonso III para promover uma nova organização do Estado). Nota-se, portanto, que Mattoso considera os reinados dos primeiros reis portugueses como fundamentais para a consolidação da figura do monarca através do aparato jurídico e lembra que:

\begin{abstract}
Foi, decerto, o conhecimento directo da realidade no Norte do país, tornada evidente para ele e para os membros da sua cúria durante as suas deslocações a norte do Mondego, que levou o rei a decidir reeditar a medida tomada em 1220 por seu pai, Afonso II, de proceder a um rigoroso levantamento dos foros e prestações devidas pelos seus súbditos e dependentes em todas as terras do reino situadas a norte do Mondego. 0 cadastro dos foros e direitos da coroa que daí resultou constitui um dos monumentos mais impressionantes legados pela administração régia portuguesa durante toda a Idade Média (MATTOSO, 2001, p. 907)
\end{abstract}

Diferentemente do FR, o LLP não apresenta uma distribuição interna organizada em torno das matérias jurídicas. As leis não são dispostas em livros, mas em títulos que obedecem a uma certa lógica cronológica. Isso porque o LLP reúne um conjunto de leis formuladas pelas cortes itinerantes dos primeiros reis portugueses. Foram reunidas aproximadamente trezentas e setenta leis que, ao contrário do FR, produzido na corte afonsina, foram redigidas ao longo dos reinados da primeira casa dinástica portuguesa e muitas delas não foram datadas. Estima-se que vinte e quatro leis tenham sido promulgadas no reinado de D. Afonso II (1185 1223), dezoito leis no reinado de Afonso III (1210 - 1279), oitenta e nove leis no reinado de D. Dinis $(1261$ - 1325) e cinquenta leis no reinado de D. Afonso IV (1291 
Revista da Seção Judiciária do Rio de Janeiro

- 1357). Tais leis, assim como as do FR, trataram de temáticas variadas, que se estendiam desde as bases ideológicas do poder real até questões como a definição de divisões patrimoniais, o funcionamento das feiras e outras temáticas cotidianas.

O interessante do LLP é que as leis nele presentes foram promulgadas como uma resposta dos monarcas às demandas imediatas dos seus súditos. As demandas eram apresentadas diretamente à corte, que se movia por todo o território, ou através dos seus procuradores, por isso as leis possuíam datas e locais de produção variados. Boa parte dessas leis representavam registros de costumes legais já existentes, ou seja, compilavam parte do direito consuetudinário, acrescido das decisões do rei que buscava assegurar para si o monopólio do poder legislador.

Antes de passarmos para a análise propriamente dita da condição jurídica das mulheres solteiras prevista nos dois códigos, é importante considerarmos brevemente a concepção de poder monárquico ibérico que permeia as legislações analisadas.

A difusão da concepção organicista de poder monárquico envolveu a produção do FR e do LLP. De acordo com ela cabia ao rei manter na corte terrestre a mesma dinâmica hierárquica e relacional que envolvia a corte celeste. Logo, assim como Cristo era o cabeça da corte e dispunha anjos e arcanjos em uma precisa hierarquia, onde cada qual possuía uma função determinada para a preservação do reino dos céus, cabia aos monarcas assumirem a liderança das suas cortes e definirem o lugar e o papel a ser desempenhado por cada um dos seus súditos, a fim de preservar a ordem e garantir a prosperidade do seu reino. Enquanto essa perspectiva acerca do poder encontra-se explicitada no livro I, Título II, Lei 2 do FR, ela se mostra diluída no LLP quando da definição e dos mecanismos de aplicação das leis nele enunciadas.

A concepção organicista de poder alimentou e fundamentou a luta jurídica dos reis castelhanos e portugueses para garantir-Ihes uma certa centralidade no exercício do poder monárquico, mas não foi de fato suficiente para alcançá-la plenamente. 
Revista da Seção Judiciária do Rio de Janeiro

A centralidade de poder foi utilizada pela historiografia, especialmente aquela ligada à história do Direito, como um critério para a definição da existência de um poder estatal no período moderno, em contraposição à anarquia de poderes e a descentralização política que teria caracterizado a Idade Média. Tal vício historiográfico difundiu-se a ponto de as monarquias medievais passarem a ser entendidas como projetos embrionários e mal acabados desenvolvidos de forma plena somente no mundo moderno.

Foi para romper com essa perspectiva que autores como José Manuel Nieto Soria, António Hespanha, Bartolomé Clavero e José Antonio Maravall empenharam-se desde a década de 1980 em combater os anacronismos que envolvem o entendimento da forma como o poder monárquico se configurou e se estabeleceu nas monarquias ibéricas medievais e modernas. Daí Nieto Soria insistir em identificar as imagens organicistas como um dos fundamentos ideológicos do poder monárquico castelhano, que justificou a elaboração de uma concepção corporativa do poder régio, onde pretendia-se difundir, especialmente através das obras legislativas, uma clara noção da função a ser desempenhada pelo monarca e dos instrumentos que possuía a seu dispor para exercê-lo.

O exercício do poder régio não deveria se dar de forma isolada, por isso a necessidade de que o monarca estabelecesse com as demais instâncias da sociedade, que representavam, por si só, espaços de poder, uma espécie de pacto de obediência e de divisão de responsabilidades para a garantia do bem comum. Esse ponto é facilmente identificável quando observamos o contexto histórico em que os dois códigos foram talhados. Tanto Afonso X, quanto os primeiros reis portugueses, tiveram que inserir na formulação das suas leis elementos que pertenciam ao costume comum das diversas municipalidades e a tradição da aplicação da justiça pelos elementos nobiliárquicos. Como nos lembra Maria Filomena Coelho:

A lógica de pertença ao corpo explica-se em chave coletiva, formada pelos laços pessoais de dependência e de fidelidades (redes sociais), o que conforma em boa medida a moral política. Nessa perspectiva, a lei do 
Revista da Seção Judiciária do Rio de Janeiro

monarca, a depender das circunstâncias, era pesada junto com outros imperativos que vinculavam e obrigavam as pessoas em sociedade. (COELHO, 2011, p. 4-5)

As concepções jurídicas que nascem na Idade Média são, portanto, originais e marcadas por peculiaridades e só assim podem ser de fato exploradas e entendidas. Ao refletir sobre os impactos da ausência da estrutura estatal romana no período medieval especialmente no campo do Direito, Paolo Grossi concluiu:

\begin{abstract}
A incompletude do poder político medieval após a derrocada desastrosa das sólidas manifestações precedentes, e o parcial vazio político que continua a existir significa uma só coisa: o grande titereiro está ausente; está ausente o sujeito político que tende a reger todos os fios, a fazer dos vários centros sociais concorrentes simples marionetes manobradas ao bel-prazer. Significa uma incrível liberdade do campo histórico, uma possibilidade de ação autônoma para uma pluralidade de presenças que, à sombra de um poder totalmente completo, veriam sua autonomia totalmente frustrada ou até mesmo expropriada. (GROSSI, 2014, p. 58)
\end{abstract}

É justamente partindo da pluralidade e das peculiaridades presentes no FR e no LLP quanto ao ordenamento da condição feminina que passamos a refletir especificamente sobre aquele que se refere às mulheres solteiras.

\title{
3 O IDEAL DA MULHER SOLTEIRA NO FUERO REAL E NO LIVRO DAS LEIS E POSTURAS
}

Os estudos promovidos por historiadores como Georges Duby e Michelle Perrot, francamente inspirados pelo diálogo com a antropologia estruturalista de Lévi-Strauss, indicaram a importância que o casamento alcançou como um dos principais instrumentos de organização da estrutura social medieval. Como concluiu Duby:

[...] Os ritos do casamento são instituídos para assegurar dentro da ordem a repartição das mulheres pelos homens, para disciplinar em volta delas a competição masculina, para oficializar, para socializar a procriação. Designados quem são os pais, eles acrescentam uma outra filiação à filiação materna, a única evidente. Eles distinguem das outras as uniões lícitas, 
Revista da Seção Judiciária do Rio de Janeiro

atribuem aos filhos que delas nascem o estatuto de herdeiros, isto é: antepassados, um nome, direitos. O casamento funda as relações de parentesco, funda a sociedade no seu todo. Ele forma a pedra angular do edifício social. (DUBY, 1981, p. 19)

Afora as questões sentimentais, não consideradas neste contexto, a união de homens e mulheres em uma relação matrimonial significava a definição de um lugar social. Os casados gozavam de um status social diferenciado, eram alvos de responsabilidades e usufruíam de privilégios específicos. Ao homem cabia a honra e a dignidade de chefiar uma família, sendo responsável pelo seu sustento e preservação. À mulher cabia, antes de tudo, gerar uma família, tornando-se mãe e depois mantê-la unida sobre os princípios da honra e da moral cristã, conforme previsto tanto no discurso clerical quanto no jurídico.

O casamento funcionava como uma espinha dorsal que sustentava a hierarquia social, principalmente no que se referia ao círculo aristocrático. Logo, tratava-se de uma prática que precisava ser regulada por aqueles que, desde o século XII, com os ventos reformistas na Igreja e as tendências centralistas do poder monárquico, buscavam ordenar a conduta daqueles pelos quais se consideravam responsáveis.

Controlar a prática matrimonial significava controlar, dentre outros pontos, a sexualidade e a transmissão e a divisão dos bens familiares, já que o casamento era, em última instância, uma decisão familiar onde o amor não constava como um pré-requisito necessário, sendo na maior parte das vezes, condenável. Como afirma Charles de la Roncière, "(...) Evidentemente, o casamento impõem-se como uma instituição indispensável, e até feliz, mas não é local de amor." ${ }^{\prime 3}$ (LA RONCIÈRE, 1985. p. 141).

Levando-se em consideração que parte da reprodução social cabia às mulheres, estas eram preparadas desde a sua infância para o casamento,

\footnotetext{
${ }^{3}$ LA RONCIÈRE,Charles de. À sombra da castidade. In: BERNOS, M.; L'ÉCRIVAIN, P.; LA RONCIÈRE, C. de la et. GUYON, Jean. O Fruto proibido. Lisboa: Edições 70, 1985. p. 141.
} 
Revista da Seção Judiciária do Rio de Janeiro

independente do seu grupo social, embora a pressão para que o matrimônio se desse sob as circunstâncias ideais fosse amplificada pela pressão parental. Logo, em uma sociedade onde o casamento era a meta, as mulheres solteiras integravam o grupo feminino a ser ainda mais preservado.

Analisando a sociedade peninsular, imersa no mesmo arcabouço moral religioso e partilhando de condições sociais e econômicas similares às do restante do Ocidente medieval, identificamos o esforço das monarquias castelhana e portuguesa para ordenar o status jurídico das mulheres solteiras.

$O$ interesse das monarquias supracitadas por controlar a licitude e a regulação das questões patrimoniais decorrentes de uma união matrimonial é explicada pelo fato de que, em sendo o cabeça do corpo social, era da responsabilidade do rei garantir não só a preservação, mas também a reprodução da sociedade. Reprodução esta que só contribuiria para o ordenamento social se ocorresse de forma legítima e sem gerar problemas patrimoniais que comprometessem os interesses familiares. Daí ser perceptível nas leis que analisamos tanto a tendência de preservar a integridade do corpo feminino, combatendo raptos e violações, quanto de garantir o direito e o acesso das mulheres ao patrimônio da sua parentela e a do seu marido, desde que as suas ações não comprometesse a integridade dos bens.

A condição jurídica das mulheres solteiras encontrava-se relacionada à possibilidade de um casamento. Havia um entendimento tanto por parte do discurso religioso quanto do jurídico da necessidade de custódia constante em relação às mulheres. Carla Casagrande, ao analisar a custódia masculina sobre as mulheres, considerou dois elementos relevantes para o seu entendimento. Em primeiro lugar, 0 fato de que apesar da diversidade dos perfis socioeconômicos das mulheres medievais, nos discursos eclesiásticos e laicos há a difusão de um modelo universal para todas as mulheres. Como lembra Casagrande, ao referir-se às mulheres medievais: "mas todas assumiam na família papéis de mulheres, mães e filhas, e a proposta de uma definição desses papéis foi um dos objetivos principais da nova 
Revista da Seção Judiciária do Rio de Janeiro

pastoral e da nova pedagogia. "4 (CASAGRANDE, 1992, p. 94). Em segundo lugar, e concordando com Jacques Dalarun, os modelos propostos, por mais que se tratassem de construções ideológicas, foram referenciados por práticas sociais e, portanto, relacionavam-se ao contexto social vivido pelas mulheres tanto quando elas afirmavam tais modelos como quando se rebelavam contra ele, encontrando brechas para transgredi-lo. Como concluiu a autora:

as mulheres tinham que conviver com as palavras daqueles homens a quem uma determinada organização social e uma preciosa ideologia haviam confiado o governo dos corpos e almas femininas. ${ }^{\prime \prime 5}$ (CASAGRANDE, 1992, p. 93).

Desde o século XII o casamento foi convertido em um sacramento. Deixou de ser um assunto que poderia ser tratado livremente pelos laicos que até então definiam as regras e legavam ao clero somente o papel coadjuvante. Até ser sacramentalizado, o casamento era contratado pelas famílias dos noivos, que além de ver na união uma forma de ampliar e/ou preservar o seu patrimônio, o consideravam como um símbolo do seu status social.

Georges Duby, em sua obra Idade Média, Idade dos Homens. Do amor e outros ensaios (1989), analisou o esforço da igreja reformista de impor a sua moral eclesiástica acerca do casamento sobre a moral laica vigente até então. A igreja pretendia limitar a autonomia de que gozava a aristocracia na contratação dos casamentos imersos em uma política patrimonial garantidora do status econômico e social familiar. Nas palavras de Duby:

Coloquemos, portanto, em primeiro lugar, frente a frente, os dois sistemas de enquadramento, os quais, por seus objetivos, são quase inteiramente estranhos um ao outro: um modelo leigo, encarregado, nessa sociedade ruralizada, na qual cada célula tem raiz num patrimônio fundiário, de preservar, geração após geração, a permanência de um modo de produção;

\footnotetext{
4 "pero todas assumían en la familia los roles de mujeres, madres e hijas, y la propuesta de una definición de esos roles fue uno de los objetivos principales de la nueva pastoral y de la nueva pedagogia" (CASAGRANDE, 1992, p. 94).

${ }^{5}$ Las mujeres tenían que convivir con las palabras de aquellos hombres a quienes una determinada organización social y una preciosa ideologia habían confiado el gobierno de los cuerpos y las almas femininas. (CASAGRANDE, 1992, p. 93).
} 
Revista da Seção Judiciária do Rio de Janeiro

um modelo eclesiástico cujo objetivo, atemporal, é refrear as pulsões da carne, isto é, reprimir o mal, represando numa moderação estrita as irrupções da sexualidade. (DUBY, 1989, p. 15)

A moral eclesiástica visava ressaltar o caráter divino do casamento, retirando dele qualquer traço de luxúria e exaltando o seu caráter procriativo, assegurando o resguardo da virgindade da noiva até que o laço matrimonial ocorresse de fato e combatendo práticas como o incesto, o repúdio e o concubinato. Para tanto, o discurso eclesiástico enfatizava quatro pontos fundamentais incorporados ao caráter matrimonial do casamento: o direito de consentimento dos noivos para a realização da união, a definição dos fatores que permitiriam a dissolução de um casamento, o estabelecimento dos critérios de licitude e a regulamentação das práticas sexuais lícitas no leito conjugal. Em virtude do nosso objeto de estudos, privilegiaremos em nossa análise somente os pontos referentes aos critérios de licitude e ao direito de consentimento dos noivos.

Os dois códigos pesquisados são unânimes em considerar legítimo somente os casamentos realizados sob as regras determinadas pela igreja. Assim diz o LLP: "Os casamentos todos se possam fazer por aquelas pessoas que a Santa Igreja manda com tanto que sejam tais que possam se casar sem pecado." ${ }^{\prime 6}$ (SILVA, 1971, p. 114). Diz o FR: "Estabelecemos e mandamos que todos os casamentos se façam por aquelas palavras que manda a santa igreja, e os que casarem sejam tais que possam casar sem pecado."7 (LA REAL ACADEMIA DE LA HISTORIA, 1836, III, I, 1, p. 64). Logo, nota-se que nos reinos de Castela e de Portugal a moral eclesiástica foi absorvida pelo discurso jurídico e ambas as coroas a utilizaram como garantia da licitude do casamento, mas guardaram para si o direito de ordenar as questões

\footnotetext{
6 "Os casamentos todos se poden fazer per aquelas perauoas (sic) que a santa Eygreia manda atando que seiam taaes que posan casar sen pecado" (LLP, p. 114).

7 "Establecemos y mandamos que todos los casamientos se fagan por aquellas palabras que manda santa iglesia, e los que casaren sean tales que puedan casar sin pecado." (LA REAL ACADEMIA DE LA HISTORIA, 1836, III, I, 1, p. 64).
} 
Revista da Seção Judiciária do Rio de Janeiro

patrimoniais dele decorrentes, bem como asseguraram o direito da parentela de preservar a honra das mulheres sob a sua guarda.

Cabe destacar, contudo, que no LLP há o "casamento por fama", que eram aquelas uniões onde o casal não era casado diante da Igreja, mas convivia em uma mesma casa há mais de sete anos contínuos, se chamava de marido e mulher, era reconhecido como tais pela vizinhança, possuía uma carta ou outro instrumento que os "fizerem marido e mulher" e realizava compras ou vendas em conjunto. Nesses casos a união deveria ser reconhecida como um casamento.

A existência do casamento por fama representa uma abertura da coroa portuguesa para o reconhecimento das uniões que não estavam submetidas ao rito eclesiástico, mas que a monarquia precisava enquadrar juridicamente a fim de garantir a sua legalidade e os atos patrimoniais delas originários. $O$ fato de este tipo de união estar na lei indica a frequência com que ele ocorria e, talvez, fosse mais frequente nas municipalidades, já que o reconhecimento da sua legalidade passava pelo testemunho dos membros da vizinhança e pela conivência das autoridades locais, responsáveis por emitir cartas de compras e vendas de bens. O casamento por fama, portanto, pode ser considerado equiparado às uniões estáveis atuais e o seu reconhecimento garantia o resguardo jurídico para as mulheres que fossem parte dele.

Um dos elementos importantes a se considerar quando se trata do casamento das donzelas está juntamente nas circunstâncias garantidoras da sua legitimidade, tanto no âmbito eclesiástico quanto no âmbito legal. O IV Concílio de Latrão, em 1215, determinou que a legitimidade do casamento estivesse condicionada a obediência a alguns critérios como: respeitar-se a proibição das relações matrimoniais abaixo do quarto grau de parentesco, a publicidade do casamento e a necessidade de consentimento dos noivos.

$\mathrm{O}$ ato do consentimento dos noivos em relação ao casamento esteve presente no FR, que condenava o pai ou qualquer outro que ousasse casar uma filha donzela 
Revista da Seção Judiciária do Rio de Janeiro

ou viúva, sem que ela expressasse o seu consentimento. Caso incorresse neste erro, o infrator deveria pagar cem maravedis, a serem divididos entre o rei e a mulher onerada. Além disso, o casamento seria invalidado. Esta pena só seria suspensa se o casamento tivesse sido feito com a aprovação do rei (LA REAL ACADEMIA DE LA HISTORIA, 1836, IV, X, 8, p. 136).

No FR, portanto, destaca-se o caráter atenuante que o consentimento régio exercia sobre a validação de um casamento realizado em uma circunstância adversa àquela prevista na moral canônica, pois caso a parentela contasse com o aval do rei para casar os seus filhos sem que consentissem na união, o casamento seria válido. Esse direito assegurado ao rei castelhano de reverter algo que se encontrava instituído, corresponde justamente a sua capacidade de representar a lei. Como explicou Nieto Soria ao analisar os fundamentos ideológicos do poder real em Castela, entre os séculos XIII e XVI:

\begin{abstract}
A função legisladora do rei se considerou em todos estes séculos em Castela geralmente, como uma dessas faculdades que recaíam sobre o monarca como consequência de sua inquestionável origem divina. O rei, enquanto rei, estava dirigido por Deus a realizar uma atividade legisladora, entre seus súditos. O poder legislador do príncipe, em definitivo, era algo querido pela divindade. (NIETO SORIA, 1988, p. 157). ${ }^{8}$
\end{abstract}

Além do consentimento dos noivos para o casamento, previsto no discurso religioso, havia um outro tipo de consentimento enunciado na lei que era aquele que deveria ser dado pela parentela para a realização de um casamento.

O FR é claro em definir a importância da obediência das filhas nas questões matrimoniais. As "mancebas em cabellos", como eram chamadas as donzelas, só poderiam se casar com o consentimento da sua parentela e com alguém que por ela fosse escolhido. Caso a donzela insistisse em casar-se sem o consentimento dos pais,

\footnotetext{
${ }^{8}$ La función legisladora del rey se considero en estos siglos en Castilla por lo general, como una de esas faculdades que recaían en el monarca como consecuencia de su incuestionable origem divino. El rey, en cuanto que rey, estaba dirigido por Dios a realizar una actividad legisladora, entre sus súbditos. El poder legislador del príncipe, en definitiva, era algo querido por la divindade. (NIETO SORIA, 1988, p. 157).
} 
Revista da Seção Judiciária do Rio de Janeiro

perderia o acesso aos seus bens, não participando mais da partilha com os seus irmãos, sendo, portanto, deserdada (LA REAL ACADEMIA DE LA HISTORIA, 1836, III, I, 3, p. 64). No entanto, se ela alcançasse o perdão dos pais, a pena seria revertida (LA REAL ACADEMIA DE LA HISTORIA, 1836, III, I, 5, p. 65).

Em um sentido contrário ao do FR, o LLP também assegurava a manceba o direito de se casar sem o consentimento da sua parentela, impedindo-a de deserdá-la (SILVA, 1971, p. 114). Contudo, no ano de 1378 foi publicada uma nova lei que condenava e punia duramente aqueles que tivessem se casado em circunstâncias onde "sobre isto não haja sacramento nenhum de justiça segundo o do direito ${ }^{9}$ (SILVA, 1971, p. 422). A justificativa dos juristas para a mudança no trato dessa questão foi a necessidade de conter uma prática que estava sendo "muito usado em nosso senhorio". E para desestimulá-la ao máximo, estabelecia-se que os bens acumulados pelo casal deveriam ser repassados para a parentela da mulher e este deveria ser desonrado. No caso dos casais que não tivessem bens e não fossem fidalgos, deveriam ser difamados, açoitados por toda a vila e expulsos da comunidade. Nota-se, portanto, que a lei previa diferenciação na punição dos envolvidos de acordo com critérios sociais. Para os fidalgos, a punição era pecuniária e moral, já para os demais, previa-se a penalidade corporal, além de toda a humilhação moral que o açoitamento implicava, pois a pena seria aplicada publicamente.

As penas de açoitamento têm uma tradição bastante longa como forma punitiva, remontando à Antiguidade, onde era aplicada levando-se em consideração o gênero e as condições socioeconômicas dos condenados. Os açoitamentos eram em geral destinados aos crimes de injúria e foram incorporados ao direito visigodo, sendo previstos no Liber Iudiciorum para a punição tanto de servos quanto de homens livres que tivessem cometido aborto, rapto, violação, sodomia, roubo, dentre outros atos criminosos. Os açoitamentos também podiam ser utilizados de forma

\footnotetext{
9 "sobre esto non auiam sacramento nenhum de justiça segundo o de dereito" (SILVA, 1971, p. 422) 
Revista da Seção Judiciária do Rio de Janeiro

combinada com outros tipos de penas. A aplicação dos açoites previstos no Fuero Juzgo se dava de forma escalonada, ou seja, deveria-se levar consideração critérios como a importância do insulto. A mesma lógica foi mantida no FR.

Como o Fuero Juzgo serviu como base para grande parte dos códigos jurídicos produzidos nos reinos ibéricos baixo-medievais, também inspirou a forma como o LLP previu o açoitamento do casal que se casasse sem o consentimento da parentela. No LLP foram previstos dois tipos de açoitamento: aquele que deveria ser feito diante do juiz, ou seja, de forma mais privada, e aquele que deveria ser aplicado publicamente, provavelmente nos dias de mercado e na praça para garantir ao castigo maior publicidade, como concluiu Patrícia Zambrana Moral (2005).

Comparando a forma como o tema foi tratado em ambas as fontes é interessante observar que enquanto no FR o monarca se mostrava como aquele que desempenhava um papel arbitral nas disputas que envolviam os noivos e a sua parentela, reforçando a noção do monarca como portador de um poder central que se sobrepunha aos demais, no LLP a figura do monarca não possui um papel definido na resolução dessa questão. A aplicação das penas previstas, especialmente a de açoitamento, parecia se encontrar mais no âmbito da comunidade, como uma espécie de resquício do direito consuetudinário, visto que a lei diz claramente: "E açoitados por toda a vila e quando isso acontecer ponham-nos fora da vila para sempre. ${ }^{\prime \prime 10}$ (SILVA, 1971, p. 422).

Um ponto interessante expresso nos dois códigos é a necessidade de legislar sobre a questão da herança da donzela. Em termos pecuniários, a maior penalidade atribuída às mulheres solteiras era a perda dos seus bens, o que implicaria na perda do único instrumento de que elas dispunham para alcançar o seu destino social ideal: o casamento.

Como alerta Georges Duby, em sua obra $O$ cavaleiro, a mulher e o padre:

\footnotetext{
${ }^{10} \mathrm{E}$ açoutados per toda la villa hu este acontecer e ponham nos fora da villa para senpre. (SILVA, 1971, p. 422).
} 
Revista da Seção Judiciária do Rio de Janeiro

[...] A função do casamento era a de juntar a um genitor valente, uma esposa de tal ordem que o seu filho legítimo, esse ser que transportaria o sangue e o nome do antepassado valoroso, fosse capaz de fazer reviver este na sua pessoa. Tudo dependia da mulher (DUBY, 1981, p. 30).

O papel fundamental da mulher no casamento era a procriação. Ter um filho era sinal de status para a mulher e fortalecia o seu lugar na parentela. Portanto, as virgens eram muito valorizadas pelas famílias na contratação dos casamentos considerados ideais. A virgindade assegurava a legitimidade do primeiro filho e herdeiro, pois a primogenitura tornou-se uma condição primordial para a delegação das heranças por volta do século XII e possui um forte teor simbólico nas sociedades desde a Antiguidade. Como alerta Yvone Knibichier, em seu livro História da Virgindade (2016), "(...) A defloração é vista como um ato mágico; simultaneamente ferida que sangra e revelação do prazer, ela supostamente provoca uma alteração definitiva na fêmea humana" (KNIBIEHLER, 2016, p. 112). Alteração essa que preparava o corpo feminino para o ato procriativo.

O casamento era tão importante para o status social feminino que não poderia ser negado a nenhuma mulher solteira. Nos dois códigos analisados foi reservado às mulheres solteiras o direito de se casar, mesmo que, em algumas circunstâncias, sem o consentimento dos seus parentes. É o caso, por exemplo, das mulheres cujo casamento não foi acordado pelos seus parentes por pretenderem apropriar-se da sua herança. Conforme se lê no FR:

Se o pai ou a mãe, os irmãos e outros parentes tiverem em seu poder manceba em cabelos e, não a casar até fazer 25 anos, e elas depois se casarem sem mandado, não haja pena sobre elas por isso, casando ela com o homem que the convier. ${ }^{11}$ (LA REAL ACADEMIA DE LA HISTORIA, 1836, III, I, 2; p. 64)

\footnotetext{
${ }^{11} \mathrm{Si}$ el padre o la madre, o hermanos o otros parientes tovieren en su poder manceba en cabellos e, non la casaren fasta XXV años, e ella despues casares sin su mandado, non aya pena por ende, casando ella con ome quel conviere. (LA REAL ACADEMIA DE LA HISTORIA, 1836, III, I, 2; p. 64)
} 
Revista da Seção Judiciária do Rio de Janeiro

A mesma determinação quanto à liberdade das donzelas para casar-se sem o consentimento da sua parentela aos vinte e cinco anos foi assegurada no LLP, em uma lei produzida em 1295 (SILVA, 1971, III, 4, p. 165). Nota-se, então, que nos dois códigos, essa era a idade em que a mulher alcançava uma certa autonomia legal frente à sua parentela.

Na Idade Média a concepção de infância não é a mesma que possuímos hoje. As crianças eram entendidas e vestidas como adultos em miniatura, recebendo sobre si também as responsabilidades próprias da maturidade. Sendo assim, a menarca era o marco de ingresso de uma mulher na vida adulta, independente da idade em que ela ocorresse e mostrava-se como uma espécie de sinal verde para que as famílias levassem à diante as tratativas para o cumprimento dos acordos matrimoniais por vezes firmados desde a infância. Tão logo a mulher estivesse pronta para cumprir a sua principal função, que era a procriação, ela seria dada em casamento àquele que foi escolhido pela sua parentela.

A autonomia que a lei dava às mulheres para casar-se sem consentimento após os vinte e cinco anos demonstrava a preocupação dos monarcas tanto em garantir que elas pudessem decidir, dentro de determinados critérios, o seu destino, ${ }^{12}$ quanto em impedir que os líderes das famílias nobiliárquicas concentrassem o patrimônio em suas mãos, comprometendo a circulação dos bens territoriais nobiliárquicos que precisava ser assegurada pelo monarca. A lógica do casamento era contratual e neste contrato estavam envolvidos os interesses dos noivos, da parentela e também os do monarca.

Um outro elemento previsto no IV Concílio de Latrão e que encontrou reforço na legislação analisada, foi o de que a validade do casamento encontrava-se condicionada à sua publicidade. Segundo esta norma, o casamento deveria ser público, realizado na presença de testemunhas e oficializado por um clérigo. A

\footnotetext{
${ }^{12}$ A lei que tratou da liberdade do casamento das mulheres após os vinte e cinco anos no FR previa que a mulher não poderia se casar com inimigos da sua parentela para que a união fosse considerada válida (LA REAL ACADEMIA DE LA HISTORIA, 1836, III, I, 6, p. 65)
} 
Revista da Seção Judiciária do Rio de Janeiro

publicidade do casamento era um fator garantidor da sua legitimidade e exigida também no FR que determinou que: "E todo casamento deve ser um conselheiro, e não um furto, para que se fosse necessário isso pudesse ser provado por muitos."13 (LA REAL ACADEMIA DE LA HISTORIA, 1836, III, I; 1, p. 64). E estabeleceu como punição para quem cometesse tal erro, o pagamento de uma pena pecuniária de cem maravedis ao rei. Caso o culpado não tivesse a quantia a ser paga, perderia todos os bens que tivesse e a sua liberdade para o rei.

A publicidade do casamento era um elemento garantidor de que a parentela e as autoridades eclesiásticas deram o seu aval para a realização do enlace, logo, casamentos que nascessem de um rapto à princípio não eram legítimos. O rapto de donzelas era uma das estratégias mais utilizadas por aqueles que, não sendo herdeiros do patrimônio familiar, viam no casamento com uma mulher nobre, a oportunidade de apropriar-se da gestão de uma herança patrimonial considerável.

Portanto, para desestimular a prática do rapto, a coroa castelhana impedia que o raptor se casasse com a mulher raptada e o punia pecuniariamente. Por essa "caloña" (termo utilizado no FR para esse ato) o raptor deveria pagar cem maravedis a serem divididos entre a mulher raptada e o rei. Caso não tivesse como pagar, o raptor seria metido na prisão até que tivesse condições de arcar com a sua dívida (LA REAL ACADEMIA DE LA HISTORIA, 1836, IV, X, 1, p. 134).

Adotando um sentido inverso, os monarcas portugueses preocuparam-se em garantir a legalidade dos casamentos "que possa ser provado quer seja por furto ou aconcelhadamente valha, mas somente se os que assim se casarem forem de idade cumprida conforme o costume ${ }^{\prime 14}$ (SILVA, 1971, p. 114). Contudo, a lei não especifica que idade seria essa, mas talvez fosse a de vinte e cinco anos.

É importante considerar que o rapto de donzelas não funcionava somente como uma estratégia para homens sem fortuna. 0 rapto de mulheres solteiras foi

\footnotetext{
${ }^{13}$ Et todo casamiento fagase concejeramiente, e non a furto, de guisa que si fuer mester que se pueda probar por muchos." (FR,III, I; 1, p. 64)

14 "se os que assy cassarem forem didade compryda como he de costume." (LLP, p. 114)
} 
Revista da Seção Judiciária do Rio de Janeiro

adotado como uma estratégia pelas famílias que pretendiam liberar-se de um casamento previamente acordado. Para essas circunstâncias o FR previa que:

Se o pai ou a mãe, ou deles consentirem no roubo de sua filha que fosse desposada, paguem ao esposo um quarto daquilo que tiveram que dar em casamento com ela: e disto haja a metade o esposo, e o que a levou por força, aja a pena da lei. ${ }^{15}$ (LA REAL ACADEMIA DE LA HISTORIA, 1836, IV, X, 6, p. 136)

O objetivo da coroa castelhana, portanto, era preservar os interesses dos noivos, impedindo que a parentela utilizasse o rapto como uma forma de romper acordos pré-definidos e a penalizando justamente com a perda de parte do valor que tinha sido acordado como arras da noiva, numa clara compensação ao esposo pela perda. Nota-se, então, a ação do monarca para garantir o ordenamento das questões patrimoniais que envolviam os casamentos, mas também uma certa abertura que a lei propiciava às donzelas que por ventura não quisessem romper os laços matrimoniais acordados e se viam pressionada a fazê-lo por ordem da sua parentela, já que o uso da palavra "roubo" indica violência e pode atestar a falta de vontade da mulher de submeter-se aquele ato.

O rapto de mulheres era moralmente condenável, pois era entendido como um ataque direto à honra da mulher raptada e da sua parentela, ainda mais se incorresse na violação, portanto deveria ser seriamente punido pela legislação régia. O rapto colocava em risco a tessitura social, enfraquecendo os laços de solidariedade entre os membros da comunidade.

A preocupação dos legisladores em tratar juridicamente dessa questão nos leva a concluir que esses atos de violação não eram incomuns, pelo contrário pareciam ser bastante frequentes na sociedade peninsular e a sua recorrência contribuía para uma possível instauração da desordem social, que as coroas castelhana e portuguesa precisavam combater.

\footnotetext{
${ }^{15}$ Sy el padre o la madre, o el uno dellos consintieren robo de su fija que fuer desposada, pechen al esposo quatro a tanto de aquello quel ovieron de dar en casamento con ella: et desto aya la meytade el esposo, e el que la levó por fuerza, aya la pena de la ley. (FR, IV, X, 6, p. 136)
} 
Revista da Seção Judiciária do Rio de Janeiro

Ao estudar o tema da violação feminina na Idade Média, Cristina Segura (2008) e Maria Teresa Arias Bautista (2016) atribuíram-na, sobretudo, à lógica patriarcal que regia a sociedade medieval. Aliás, as duas autoras são unânimes em afirmar que o patriarcalismo não foi exclusivo do período medieval, mas esteve presente nas sociedades antigas e sobreviveu à Idade Média, onde coadunou-se ao discurso moral cristão, e encontra-se presente na sociedade contemporânea.

O patriarcalismo não só previa a submissão das mulheres aos homens, mas também definia o papel social que deveria ser desempenhado por ambos na sociedade medieval. A cultura patriarcal preservada nas relações de parentesco hierarquizava os indivíduos e ordenava a sociedade. Como concluiu Georges Duby, "[...] Raros são os aspectos da civilização medieval que não podem ser esclarecidos de algum modo pelo conhecimento das estruturas de parentesco." (DUBY, 1989, p. 103).

Nos casos de definição do que pode ser considerado legalmente como um ato de violação passível de ser punido, a posição que os criminosos e as suas vítimas ocupavam na escala social era um fator determinante. Era considerado como violação tomar uma mulher à força sem o seu consentimento, mas não há casos nos dois códigos que legislem sobre a violação de mulheres por membros da sua parentela. Logo, parece ter sido entendido como um crime de violação aquele que envolvesse mulheres e homens que não tivessem a obrigação parental de custodiá-las.

No caso de um homem que levasse uma mulher solteira à força e não a violasse, a penalidade prevista, no $\mathrm{FR}$, era o pagamento de 100 maravedis:

[...] e se não houver como os pagar, perca o que tiver, e fique preso até que cumpra os cem maravédis, e desta calúnia, haja metade ao rei e a outra metade à mulher que prendeu à força. ${ }^{16}$ (LA REAL ACADEMIA DE LA HISTORIA, 1836, IV, X, 1, p. 134).

\footnotetext{
16 "[...] e si non ovier de que los pechar, perda lo que oviere, e yaga en prision fasta que cumpla los c maravédis; e desta caloña, aya la meytad el rey e la otra meytad la luger que prisó la fuerza." (FR, IV, $\mathrm{X}, 1$, p. 134)
} 
Revista da Seção Judiciária do Rio de Janeiro

Nota-se, então, que apesar de os juristas afonsinos preverem uma certa autonomia legal para essas mulheres, Ihes garantindo uma compensação econômica ao destinar-lhes metade da pecúnia paga pelo seu violador, também inseriram a defesa da honra feminina na esfera do poder monárquico, visto que a outra metade do pagamento deveria ser repassada aos cofres régios.

A abordagem dada para a violação de mulheres no LLP é bastante diferenciada daquela adotada no FR. O LLP lançava sobre a mulher todo o peso na busca pela justiça para o ato criminoso. Para atestar que havia sido violada: a mulher deveria bradar e fazer sinais demonstrando que havia sido forçada, além de chorar e fazer queixumes. Também deveria dizer a quem achasse pela frente que fora forçada e dizer o nome de quem the fez o mal, caso o soubesse. Após expor-se publicamente nas ruas do povoado, deveria ir diretamente ao juiz e dizer-lhe o nome de quem a forçou "e assim provar a força pelo costume."17 (SILVA, 1971, p. 313). É clara, portanto, a indicação na fonte de que a mulher precisava expor-se publicamente, diante de toda a vila, para alcançar algum tipo de justiça e nessa lei em específico não se tem indicações de como o violador seria penalizado. Para alcançar a justiça devida, portanto, a mulher precisava expor a sua desonra publicamente, o que provavelmente não era um comportamento adotado pelas mulheres nobres, que exporiam não só a sua honra, mas também a da sua parentela.

A violação de uma mulher praticamente eliminava as suas chances de casar-se, dessa forma, o seu futuro poderia ser a prostituição. Mesmo fora da aristocracia, a virgindade era um valor a ser preservado ou mesmo negociado por famílias pobres que, não tendo como sobreviver, deixavam as suas filhas aos cuidados dos proxenetas. No caso de uma mulher violada, a prostituição era quase um caminho certo. Como alertou Jacques Rossiaud:

\footnotetext{
17 "E assy prouara a força pelo costume" (LLP, 329).
} 
Revista da Seção Judiciária do Rio de Janeiro

[...] A vítima, quase sempre difamada, esbarra com dificuldades de reinserção social e mesmo familiar. Se solteira, o seu preço diminui no mercado do matrimônio: casada, às vezes é abandonada pelo marido. Aos olhos dos vizinhos - mesmo se testemunharam a seu favor - ela parece degradada pelo que sofreu. (ROSSIAUD, 1991, p. 38).

Apesar da recorrência da prostituição especialmente nos núcleos urbanos e francamente estimulada pela transumância de guerreiros, comerciantes e outros tipos sociais, a prática em si era desestimulada pela legislação analisada. Enquanto no FR os juristas não fizeram menção direta à prostituição, o LLP lançou duras penalidades às mulheres que a praticasse. Caso a mulher fosse pega pela primeira vez se prostituindo, seria açoitada por toda a vida e perderia todos os seus bens, se os tivesse, mas se fosse reincidente, deveria ser penalizada com a morte (SILVA, 1971, 421). A rigidez da punição nos parece muito mais uma tentativa da monarquia de desestimular ao máximo essa prática do que medidas que de fato fossem implantadas. Nesse caso a lei funcionaria mais como um elemento disciplinarizador do que propriamente punitivo.

Um outro caminho possível para as donzelas era a entrada na vida religiosa. 0 FR permitia que as mulheres desposadas abraçassem a vida eclesiástica, mas somente se o casamento não houvesse sido consumado, ou seja, se ainda fossem donzelas. As mulheres religiosas desfrutavam de uma proteção especial da monarquia castelhana a ponto do FR determinar a pena de morte para os que violassem uma mulher de ordem, como previsto no livro 4, título 10, lei 4: "Quem monja ou outra mulher de ordem levar por força, quer aja com ela quer não, morra por isso."18(LA REAL ACADEMIA DE LA HISTORIA, 1836, p. 135)

\footnotetext{
18 "Quien monja o outra muger de orden levare por fuerza, quier aya que veer con ella quier non, nuera por ello." (LA REAL ACADEMIA DE LA HISTORIA, 1836, IV, X, 4, p. 135).
} 
Revista da Seção Judiciária do Rio de Janeiro

\section{CONCLUSÃO}

A partir da análise do FR e do LLP pudemos identificar os critérios definidores da condição jurídica das mulheres solteiras nos reinos de Castela e Portugal, em grande parte pautados nas referências morais eclesiásticas, que se basearam, sobretudo no ordenamento do seu acesso patrimonial, na preservação da sua honra e na garantia de um comportamento adequado aos princípios morais.

Em um contexto onde os monarcas enfrentavam o desafio de ordenar as relações sociais, econômicas e políticas que reuniam ou contrapunham monarcas, aristocratas e municipalidades, mantendo a integridade dos territórios arduamente retomados das forças muçulmanas, estabelecer critérios para que as mulheres solteiras pudessem atuar juridicamente ou mesmo ter a sua atuação devidamente punida se fazia necessário. Tal necessidade advinda principalmente do fato de que essas mulheres eram aquelas que garantiriam que o patrimônio familiar fosse constituído e ampliado, através de um bom casamento, e preservado, ao assegurar-se, através das penalizações adequadas, que o seu comportamento seria moralmente aceitável e compatível com os papéis sociais a elas destinados: filhas, esposas e mães.

Aquelas mulheres que por circunstâncias outras não conseguissem desempenhar os referidos papéis, também precisavam ter a sua condição jurídica definida e as suas ações ordenadas. Daí haver tanto no FR quanto no LLP determinações legais e mecanismos penais referentes ao desestímulo à prostituição e ao adultério e a preservação da honra e da integridade das mulheres religiosas. 
Revista da Seção Judiciária do Rio de Janeiro

\section{REFERÊNCIAS}

\section{Fontes}

LA REAL ACADEMIA DE LA HISTORIA (org.). Fuero Real del rey Don Alonso El Sabio. Madrid: Imprenta Real, 1836.

SILVA, Nuno Espinosa Gomes da. Livro das Leis e Posturas. Lisboa: Faculdade de Direito da Universidade de Lisboa, 1971. Disponível em http://www.governodosoutros.ics.ul.pt/?menu=consulta\&id_partes $=43 \&$ accao=ver\& pagina=4. Acesso em: 30 out. 2021.

\section{Bibliografia}

ARIAS BAUTISTA, Maria Teresa. Victimas y victimarias. Violencias y mujeres en la Edad Media. [s. I.: s. n.], 2016. E-book.

BOLTON, B. A Reforma na Idade Média. Lisboa: Edições 70, 1983.

CASAGRANDE, Carla. La Mujer Custodiada. In: DUBY, G.; PERROT, M. Historia de las mujeres. La Edad Media. Madrid: Taurus, 1992.

CLAVERO, B. Introdução Histórica ao Direito. Lisboa: Fundação Calouste Gulbenkian, 1995.

COELHO, M. F. Revisitando o problema da centralização do poder na Idade Média. Reflexões historiográficas. In: XXVI Simpósio Nacional de História - ANPUH, 26, 2011, São Paulo. Anais [...]. São Paulo: ANPUH, 2011. Disponível em: http://www.snh2011.anpuh.org/resources/anais/14/1312820436_ARQUIVO_COELHO MF-Revisitando(textofinal).pdf. Acesso em: 30 out. 2021.

DUBY, G. 0 cavaleiro, a mulher e o padre. Lisboa: Dom Quixote, 1981.

DUBY, G. Idade Média, idade dos homens: Do amor e outros ensaios. São Paulo: Companhia das Letras, 1989.

GROSSI, Paolo. A ordem jurídica medieval. São Paulo: WMF Martins Fontes, 2014.

IGLESIA FERREIRÓS, J. R. Alfonso $X$ el Sabio y su obra legislativa. Anuario de Historia del Derecho español, [s. I.], n. 50, p. 531 - 562, 1980.

KNIBIEHLER, Yvonne. História da Virgindade. São Paulo: Contexto, 2016. 
Revista da Seção Judiciária do Rio de Janeiro

LA RONCIÈRE, Charles de. À sombra da castidade. In: BERNOS, M.; L'ÉCRIVAIN, P.; LA RONCIÈRE, C. de la et.; GUYON, Jean. O Fruto proibido. Lisboa: Edições 70, 1985. p. 141.

MATTOSO, J. O triunfo da monarquia portuguesa: 1258-1264. Análise Social, [s. I.], v. 35, n. 157, p. $899-936,2001$.

MORAL, P. Z. Tipología De Penas Corporales Medievales. Quadernos de Criminología: revista de criminología y ciencias forenses, [s. I.], n. 11, p. 6-12, 2010. Disponível em: https://dialnet.unirioja.es/servlet/articulo?codigo=3359370. Acesso em: 01 dez. 2021.

NIETO SORIA, José Manuel. Fundamentos ideológicos del poder real en castilla (siglos XII-XVI). Espanha: Martins Fontes, 1988.

RÉMOND, René. Por uma história política I. 2. ed. Rio de Janeiro: Editora FGV, 2003.

ROSSIAUD, J. A prostituição na Idade Média. Rio de Janeiro: Paz e terra, 1991.

RUCQUOI, Adeline. História Medieval da Península Ibérica. Lisboa: Editorial Estampa, 2005.

SCHIOPPA, A. P. História do Direito na Europa: Da Idade Média à Idade Contemporânea. São Paulo: Martins Fontes, 2014.

SEGURA, Cristina. La violencia sobre las mujeres en la Edad Media. Estado de la cuestión. Clio \& Crimen, n. 5, p. 24 - 38, 2008. Disponível em: http://www.durango-udala.net/portalDurango/RecursosWeb/DOCUMENTOS/1/1_515 _1.pdf. Acesso em: 30 out. 2021 